\title{
ANALYSIS OF WORKING CAPITAL FINANCING MEMBER OF REVENUES IN CONVENTIONAL AND ISLAMIC COOPERATION \\ Dian Lestari
}

Fakultas Ekonomi Universitas Negeri Jakarta dianlestari.302@gmail.com

Saparuddin Mukhtar

Fakultas Ekonomi Universitas Negeri Jakarta Itunk77@gmail.com

\section{Herlitah}

Fakultas Ekonomi Universitas Negeri Jakarta herlitah@unj.ac.id

\begin{abstract}
This study aims to determine the effect of working capital financing on revenues of members businesses at PEMK Cengkareng Timur Cooperative and BMT Ta'awun Finance, the difference of revenues of members businesses after and before receiving working capital financing from PEMK Cengkareng Timur Cooperative and BMT Ta'awun Finance, and difference revenues of members businesses after receiving working capital financing between Koperasi PEMK Cengkareng Timur and BMT Ta'awun Finace. Methods of data acquisition used with structured interview methods and in-depth interviews. The population in the study were all members who received working capital financing in 2016 at PEMK Cengkareng Timur Cooperative and BMT Ta'awun Finace. The sample used is 30 members from each cooperative with sampling technique in the form of census and purposive sampling. Data analysis used is multiple regression analysis, paired t sample test, and independent t test sample test. The result of research is showed there is the effect of working capital finance with revenues of members businesses at PEMK Cengkareng Timur tount $(2,142)>t_{\text {table }}(2.048)$ and in BMT Ta'awun Finance $t_{\text {count }}(2,688)>t t_{\text {able }}(2.048)$, there is difference before and after working capital financing to revenues of members businesses in both cooperatives because of the probability value of $0,000<0.05$, and there is a difference in the income of members who receive working capital financing from the two cooperatives seen from $t_{\text {count }} 0.00<0.05$.
\end{abstract}

Keywords: Working Capital Financing, Revenues of Members Businesses

\section{PENDAHULUAN}

Manusia memiliki kebutuhan hidup yang begitu kompleks dengan alat pemuas kebutuhan yang sangat terbatas. Kebutuhan ini tidak bisa dihindari dan terus merangkak naik untuk dapat dipenuhi. Banyaknya jumlah tenaga kerja yang berbanding terbalik dengan kesempatan kerja, menyebabkan angka pengangguran semakin tinggi. Pengangguran mengakibatkan manusia semakin kesulitan dalam memenuhi kebutuhan hidup, ditambah tidak adanya pemasukan yang dapat membiayai seluruh pengeluaran. Melonjaknya angka tenaga kerja terselubung dengan 
upah minumum juga menjadi faktor penghambat dalam memenuhi kebutuhan. Hal ini disebabkan karena peningkatan kebutuhan yang tidak diiringi oleh peningkatan pendapatan. Adanya fenomena ini, mendorong manusia untuk melakukan sesuatu demi memenuhi kebutuhannya yang semakin lama semakin berkembang.

Salah satu alternatif yang dipilih untuk mengatasi masalah tersebut, ditempuh dengan cara menciptakan lapangan pekerjaan sendiri atau mendirikan usaha. Usaha mikro bisa dikatakan menjanjikan bagi masa depan ekonomi nasional, namun seringkali alternatif ini menimbulkan masalah baru yang harus diselesaikan, yaitu ketersediaan modal yang harus dimiliki.

Modal merupakan elemen yang sangat penting dalam mendirikan usaha. Tanpa ketersediaan modal, pendirian usaha tidak dapat berjalan dengan baik. Bahkan seringkali kecukupan modal menjadi syarat mutlak yang mendominasi, meskipun usaha yang akan ditekuni masih dalam lingkup skala kecil. Ketersediaan modal juga menjadi masalah klasik yang harus dipenuhi agar pendirian usaha yang direncanakan dapat segera direalisasikan. Alhasil, manusia kembali dihadapkan pada pemenuhan kebutuhan yang dilatarbelakangi oleh kebutuhan akan dana atau modal. Kebutuhan inilah yang mendorong manusia untuk berhubungan dengan lembaga keuangan formal, seperti bank.

Bank merupakan lembaga intermediasi yang bertugas menghimpun dana dari masyarakat berupa simpanan dan menyalurkannya kembali dalam bentuk pinjaman. Mengajukan permohonan dana di bank tentu tidak semudah mengembalikkan telapak tangan. Masyarakat lapisan bawah pada umumnya nyaris tidak tersentuh (undeserved) dan tidak dianggap memiliki potensi dana oleh bank sehingga menyebabkan laju pertumbuhan ekonominya terhambat pada tingkat subsistensi saja.

Pengusaha ekonomi mikro tidak memperoleh aksesibilitas yang mudah. Bank lebih tertarik memberikan modal kepada para pengusaha besar dibandingkan dengan pengusaha mikro. Diskriminasi ini membuat pelaku usaha mikro tidak dapat berkembang hanya karena persoalan dana yang tidak bisa didapatkan dari fasilitas pembiayaan bank. Persoalan semacam ini membutuhkan kehadiran lembaga non bank yang dapat memberikan aksesibilitas lebih mudah dan mitra yang baik bagi para pelaku usaha mikro, seperti koperasi.

Koperasi hadir sebagai lembaga keuangan non bank yang menjanjikan dan dikhususkan untuk menjangkau masyarakat lapisan bawah atau para pelaku usaha mikro yang tidak dilirik oleh perbankan. Koperasi tumbuh dan didirikan sebagai gerakan ekonomi rakyat yang bertugas memberikan permodalan bagi masyarakat yang membutuhkan. Permodalan yang diberikan koperasi disalurkan dalam bentuk pembiayaan. Pembiayaan yang biasa digunakan adalah pembiayaan modal kerja yang kerap kali dibutuhkan untuk menambah modal kerja para pengusaha mikro. Pembiayaan ini diharapkan mampu meningkatkan pendapatan usaha dari anggota koperasi.

Setiap pembiayaan modal kerja yang disalurkan, koperasi memungut bunga di setiap transaksinya sebagai pendapatan. Anggota yang menggunakan jasa pembiayaan dari koperasi, harus mengembalikan 
pinjaman beserta bunga yang telah ditentukan. Sistem bunga yang dipungut koperasi tidak memberikan jaminan bahwa anggota dapat melunasi utangnya. Hal ini juga dilatarbelakangi pendapatan anggota yang tidak dapat dipastikan setiap harinya. Problematika tentang suku bunga, mampu mendorong koperasi jasa keuangan berbasis syariah yang dikenal dengan istilah KJKS atau Baitul Mal wat Tamwill (BMT) sebagai solusi.

Bailtul Maal wat Tamwiil (BMT) Ta'awun Finance menggunakan sistem bagi hasil antara $1-6 \%$ dari keuntungan yang diperoleh anggota. Penentuan angka ini tergantung dari hasil analisis BMT terhadap kemampuan usaha anggota untuk mengembalikan pembiayaan dan prospek keuntungan yang diperkirakan. Berbeda dengan koperasi Pemberdayaan Ekonomi Masyarakat Kelurahan (PEMK) Cengkareng Timur menetapkan bunga sebesar $2 \%$ dari setiap pembiayaan yang disalurkan.

Berdasarkan latar belakang ini, penulis ingin mengetahui sejauh mana pembiayaan modal kerja yang diberikan masing - masing koperasi mampu mempengaruhi pendapatan usaha anggota. Penulis juga ingin mengetahui apakah terdapat perbedaan pendapatan antara sebelum dan setelah menerima pembiayaan, baik di koperasi PEMK Cengkareng Timur maupun di BMT Ta'awun Finance. Terakhir, peneliti ingin mengetahui apakah terdapat perbedaan pendapatan usaha anggota antara koperasi PEMK Cengkareng Timur dengan BMT Ta'awun Finance setelah menerima pembiayaan modal kerja.

\section{KAJIAN PUSTAKA}

\section{Pendapatan}

Setiap pengusaha yang membuka usaha pasti mengharapkan memperoleh pendapatan yang tinggi untuk meningkatkan daya saing antar pengusaha yang satu dengan yang lainnya. Tingkat pendapatan yang tinggi dapat menentukan arah perusahaan di masa mendatang. Berkembang tidaknya suatu perusahaan, dilihat dari seberapa besar pendapatan yang diterima. Hal ini dikarenakan untuk melangsungkan hidupnya, suatu perusahaan harus berada dalam keadaan yang menguntungkan atau profitable. Tanpa keuntungan akan sulit bagi perusahaan untuk memperluas jaringan usahanya.

Pendapatan adalah arus masuk bruto dari manfaat ekonomi yang timbul dari aktivitas normal perusahaan selama suatu periode bila arus masuk itu mengakibatkan kenaikan ekuitas (modal), yang tidak berasal dari kontribusi penanaman modal (PSAK No. 23, 2). Pendapatan juga dapat diartikan sebagai jumlah uang penjualan ditambah pendapatan lain yang diterima dari berbagai sumber seperti bunga, dividen, dan sewa (Mahfoedz. 2007). Pendapatan terjadi karena pelaksanaan aktivitas perusahaan yang biasa dan dikenal dengan sebutan yang berbeda, seperti penjualan barang, imbalan atas jasa, bunga, dividen, royalti, dan sewa (Gunadi, 2009).

Senada dengan ketiga ahli di atas, pendapatan merupakan arus kas, pembayaran utang atau keduanya selama suatu periode tertentu yang disebabkan oleh penjualan jasa atau barang yang diproduksi. Pendapatan juga bisa berasal dari aktivitas lain yang dimasukkan ke dalam pembukuan organisasi. Ada dua macam pendapatan, yaitu (1) Pendapatan yang timbul dari aktivitas 
menguntungkan yang sifatnya berulang - ulang atau berkelanjutan dan (2) Pendapatan yang berasal dari transaksi pada suatu saat tertentu, misalnya penjualan tanah dan gudang (Margaretha, 2011).

\section{Pembiayaan Modal Kerja}

Kebutuhan masyarakat yang sangat kompleks tidak selamanya bisa dipenuhi secara langsung. Keterbatasan dana menjadi salah satu faktor yang mengakibatkan masyarakat harus melakukan transaksi dengan cara berhutang atau meminjam uang kepada pihak lain. Istilah meminjam uang sama hal nya dengan kredit atau pembiayaan. Kata kredit biasa digunakan untuk lembaga keuangan konvensional sedangkan pembiayaan digunakan untuk lembaga berbasis syariah.

Menurut Undang - Undang Perbankan Nomor 10 Tahun 1998 kredit adalah penyediaan uang atau tagihan yang dapat dipersamakan dengan itu, berdasarkan persetujuan atau kesepakatan pinjam meminjam antara bank dengan pihak lain yang mewajibkan pihak peminjam melunasi utangnya setelah jangka waktu tertentu dengan pemberian bunga. Senada dengan itu, pembiayaan adalah penyediaan uang atau tagihan yang dapat dipersamakan dengan itu, berdasarkan persetujuan atau kesepakatan pinjam meminjam antara bank dengan pihak lain yang mewajibkan pihak peminjam melunasi utangnya setelah jangka waktu tertentu dengan pemberian bagi hasil.

Kredit atau pembiayaan memiliki jenis yang beragam. Salah satu kredit atau pembiayaan yang paling dibutuhkan guna kelangsungan usaha adalah kredit atau pembiayaan modal kerja. Para ahli memiliki berbagai pandangan dan pendapat mengenai pengertiannya.

Kredit modal kerja adalah pinjaman yang bersifat jangka pendek atau jangka menengah (medium term). Pinjaman jangka pendek ini harus dibayar lunas dalam waktu semusim, bisa dengan jaminan dan bisa dengan tidak. Pinjaman jangka menengah umumnya diberikan untuk jangka waktu tiga tahun dan biasanya diberikan dengan jaminan. Tentang berapa besarnya kredit yang bisa diberikan tergantung dari kondisi keuangan koperasi yang bersangkutan, manajemennya, dan kemampuan untuk membayarnya (Hendrojogi, 2012).

Senada dengan di atas, kredit modal kerja adalah kredit yang dimaksudkan untuk membiayai bahan baku, membayar gaji, biaya operasional, piutang, dn lain - lain (Widyatmoko, 2005). kredit modal kerja juga dapat diartikan sebagai kredit yang digunakan untuk memenuhi kebutuhan modal kerja yang biasanya habis dalam satu siklus usaha (Ismail, 2011).

Sama halnya dengan kredit modal kerja, pembiayaan modal kerja adalah pembiayaan untuk memenuhi kebutuhan peningkatan produksi, baik secara kuantitatif, yaitu jumlah hasil produksi, maupun secara kualitatif yaitu peningkatan kualitas atau mutu hasil produksi dan untuk kepeluan peradagangan atau peningkatan utility of place dari suatu barang (Nikensari, 2012). Pembiayaan modal kerja syariah juga dapat diartikan sebagai pembiayaan jangka pendek yang diberikan kepada perusahaan untuk membiayai kebutuhan modal kerja usahanya berdasakan prinsip-prinsip syariah (Sholihin,2010). Berdasarkan prinsip syariah, pembiayaan modal kerja menggunakan 
enam akad dalam menjalankan transaksinya, yang terdiri dari akad mudharabah, musyarakah, murabahah, istishna, salam, dan ijarah.

Pertama, mudharabah adalah akad kerja sama suatu usaha dua pihak di mana pihak pertama (malik, shahib almal, LKS) menyediakan seluruh modal, sedangkan pihak kedua ('amil, mudharib, nasabah) bertindak selaku pengelola, dana keuntungan usaha dibagi di antara mereka sesuai kesepakatan yang dituangkan dalam kontrak (Sahroni dan Karim 2015). Kedua, akad musyarakah, adalah perjanjian antara Institutions offering Islamic Financial Services (IIFS) dan nasabah dimana IIFS berkontribusi modal dalam sebuah usaha, baik usaha yang sudah berjalan maupun usaha baru, atau usaha sementara maupun permanen, keuntungan didapatkan dari usaha dan bagi hasil sesuai dengan perjanjian meskipun rugi proporsi kerugian tetap dibagi kepada pemberi modal (Tiby, 2011).

Ketiga, akad murabahah yakni mengacu kepada penjualan barang dengan kesepakatan awal untuk menentukan keuntungan dari harga barang yang ditentukan (Kettel, 2011). Keempat, salam merupakan transakis jual beli yang barangnya sendiri belum ada dan pembayarannya secara tunai. Bank bertindak sebagai pembeli sedangkan nasabah sebagai penjual (Saiija dan Taufiq, 2016).

Kelima, istishna yakni jual beli barang dalam bentuk pemesanan pembuatan barang berdasarkan persyaratan serta kriteria tertentu sedangkan pola pembayaran dapat dilakukan sesuai dengan kesepakatan (dapat dilakukan di depan atau pada saat pengiriman barang) (Suangkupon,
2014). Keenam, ijarah adalah akad pemindahan hak guna (manfaat) atas suatu barang dalam waktu tertentu dengan pembayaran sewa tanpa diikuti dengan pemindahan kepemilikan barang itu sendiri (Ikit, 2015).

\section{METODE PENELITIAN}

Penelitian yang dilakukan adalah penelitian kuantitatif dengan menggunakan dua data, yaitu data primer dan data sekunder. Data primer diperoleh melalui hasil wawancara terstruktur dan wawancara mendalam (in-depth interviewer) kepada anggota pembiayaan modal kerja sedangkan data sekunder diperoleh melalui studi pustaka, jurnal penelitian, internet, dan data yang tersedia di kedua tempat penelitian.

Populasi dalam penelitian ini adalah seluruh anggota koperasi yang menerima pembiayaan modal kerja pada tahun 2016. Sehubungan dengan populasi pada BMT Ta'awun Finance hanya sebanyak 30 orang, maka teknik pengambilan sampel yang digunakan adalah sensus. Peneliti mengambil keseluruhan populasi untuk dijadikan sampel. Teknik pengambilan sampel pada koperasi PEMK Cengkareng Timur adalah purposive sampling, yaitu memilih sampel sesuai kriteria penelitian sebanyak 30 orang. Teknik analisis data yang digunakan dalam penelitian ini meliputi tiga analisis, yakni analisis regresi sederhana, analisis paired $t$ sample test, dan analisis independent $t$ sample test.

\section{HASIL PENELITIAN}

Pengaruh Pembiayaan Modal Kerja Terhadap Pendapatan

$\begin{array}{ccc}\text { Persamaan } & \text { regresi } & \text { yang } \\ \text { dilakukan adalah } & \text { regresi } & \text { linier } \\ \text { sederhana. Persamaan } & \text { regresi } & \text { tersebut }\end{array}$


bertujuan untuk mengetahui apakah terdapat hubungan antara variabel $\mathrm{X}$, jumlah pembiayaan modal kerja dengan variabel Y, pendapatan usaha anggota.

Tabel. 1

Hasil Regresi Sederhana Koperasi PEMK Cengkareng Timur Coefficients $^{\mathrm{a}}$

\begin{tabular}{|c|c|c|c|c|c|}
\hline \multirow[b]{2}{*}{ Model } & \multicolumn{2}{|c|}{$\begin{array}{c}\text { Unstandardized } \\
\text { Coefficients }\end{array}$} & \multirow{2}{*}{\begin{tabular}{|c|}
$\begin{array}{c}\text { Standardized } \\
\text { Coefficients }\end{array}$ \\
Beta
\end{tabular}} & \multirow[b]{2}{*}{$\mathrm{T}$} & \multirow[b]{2}{*}{ Sig. } \\
\hline & B & Std. Error & & & \\
\hline $1($ Constant $)$ & ,121 & ,029 & & 4,201 &, 000 \\
\hline $\begin{array}{l}\text { Pembiayaan Modal } \\
\text { Kerja (Konven) }\end{array}$ & ,376 & , 176 & ,375 & 2,142 & ,041 \\
\hline
\end{tabular}

a. Dependent Variable: Pendapatan Usaha Anggota (Konven-Sesudah)

Sumber : Data primer diolah dengan SPSS tahun 2017

Persamaan regresi linear sederhana untuk koperasi PEMK Cengkareng Timur yang digunakan dalam penelitian ini dapat dijelaskan sebagai berikut :

$$
\hat{Y}=0,121+0,376 \mathrm{X}
$$

a) Konstanta sebesar 0,121 menunjukkan bahwa Y (Pendapatan Usaha Anggota) akan bernilai 0,121 jika semua variabel independen dianggap konstan atau tetap.

b) Koefisien regresi untuk variabel bebas X (Jumlah Pembiayaan Modal Kerja) menunjukkan adanya pengaruh antara jumlah pembiayaan modal kerja dengan pendapatan usaha anggota. Koefisien regresi variabel $\mathrm{X}$ sebesar 0,376 , artinya variabel lainnya tetap dan pembiayaan modal kerja mengalami kenaikan. Koefisien bernilai positif artinya terjadi pengaruh yang positif antara jumlah pembiayaan modal kerja dengan pendapatan usaha anggota, semakin naik jumlah pembiayaan modal kerja maka semakin naik pendapatan usaha anggota.

Berdasarkan hasil output tersebut, thitung untuk jumlah pembiayaan modal kerja sebesar 2,142 dan $t_{\text {tabel }}$ dapat dicari dengan taraf signifikansi $0,05 / 2=$ 0,025 dengan df (n-2) atau 30-2=28. Didapat $t_{\text {tabel }}$ adalah 2,048. Dapat diketahui bahwa thitung $(2,142)>t_{\text {tabel }}$ $(2,048)$ sehingga hipotesis $\mathrm{H}_{\mathrm{o}}$ ditolak. Maka dapat disimpulkan terdapat pengaruh yang positif dan signifikan antara jumlah pembiayaan modal kerja dengan pendapatan usaha anggota pada koperasi PEMK Cengkareng Timur.

Penelitian ini juga diperkuat oleh Amir Halid, Ria Indriani, dan Delvi Suleman pada tahun 2014 tentang "Pengaruh Jumlah Kredit dan Suku Bunga Terhadap Pendapatan Usaha Mikro di BRI Unit Kabila”. Hasil signifikan uji $t$ menunjukkan jumlah kredit berpengaruh nyata karena nilai siginifikan lebih kecil dari nilai 0,05 (sebesar 0,000) yang artinya penggunaan jumlah kredit berpengaruh sangat nyata pada pendapatan usaha mikro nasabah BRI unit Kabila.

Penelitian ini juga diperkuat oleh Cut Yusriati, Muhammad Arfan dan M. Rizal Yahya pada tahun 2012 mengenai "Pengaruh Pinjaman Modal Kerja dan Profesionalisme Sumber Daya Manusia Terhadap Laba Usaha Kecil Menengah 
Kota Banda Aceh". Hasil penelitian menunjukkan nilai thitung $(3,266)$ variabel pinjaman modal kerja lebih besar dari nilai $t_{\text {tabel }}(1,684)$ maka pinjaman modal kerja berpengaruh signifikan terhadap laba UKM di Kota Banda Aceh.

Hasil penelitian juga didukung dengan pernyataan yang dijelaskan oleh Bapak Karis pada wawancara mendalam. Dia membenarkan bahwa pembiayaan modal kerja yang diberikan koperasi dapat membantu membeli bahan - bahan yang dibutuhkan untuk berdagang, seperti membeli beraneka jenis sayur - sayuran. Sayur - sayuran tersebut diolah menjadi lauk - pauk dan dijual. Pembeli pun lebih tertarik dengan barang dagang yang ditawarkan karena variasinya yang kini beragam akibat adanya penambahan jumlah dan jenis hidangan yang disajikan. Secara otomatis pembiayaan modal kerja yang dia terima memberikan dampak terhadap pendapatannya berjualan sayuran matang.

Tabel di bawah ini menerangkan hasil regresi sederhana BMT Ta'awun Finance sebagai berikut:

Tabel. 2

Hasil Regresi Sederhana BMT Ta'awun Finance Coefficients $^{\mathrm{a}}$

\begin{tabular}{|c|c|c|c|c|c|}
\hline \multirow[b]{2}{*}{ Model } & \multicolumn{2}{|c|}{$\begin{array}{c}\text { Unstandardized } \\
\text { Coefficients }\end{array}$} & \multirow{2}{*}{\begin{tabular}{|c|}
$\begin{array}{c}\text { Standardized } \\
\text { Coefficients }\end{array}$ \\
Beta \\
\end{tabular}} & \multirow[b]{2}{*}{$\mathrm{T}$} & \multirow[b]{2}{*}{ Sig. } \\
\hline & $\mathrm{B}$ & Std. Error & & & \\
\hline $1 \quad$ (Constant) & ,215 &, 021 & & 10,078 &, 000 \\
\hline $\begin{array}{l}\text { Pembiayaan Modal } \\
\text { Kerja (Syariah) }\end{array}$ &, 174 &, 065 & 453 & 2,688 & 012, \\
\hline
\end{tabular}

a. Dependent Variable: Pendapatan Usaha Anggota (Syariah-Sesudah)

Sumber : Data primer diolah dengan SPSS tahun 2017

Persamaan regresi linear sederhana untuk BMT Ta'awun Finance yang digunakan dalam penelitian ini dapat dijelaskan sebagai berikut :

$$
\hat{Y}=0,215+0,174 X
$$

a) Konstanta sebesar 0,215 menunjukkan bahwa Y (Pendapatan Usaha Anggota) akan bernilai 0,174 jika semua variabel independen dianggap konstan atau tetap.

b) Koefisien regresi untuk variabel bebas X (Jumlah Pembiayaan Modal Kerja) menunjukkan adanya pengaruh antara jumlah pembiayaan modal kerja dengan pendapatan usaha anggota. Koefisien regresi variabel X sebesar 0,174, artinya jika variabel lainnya tetap dan pembiayaan modal kerja mengalami kenaikan. Koefisien bernilai positif artinya terjadi pengaruh yang positif antara jumlah pembiayaan modal kerja dengan pendapatan usaha anggota, semakin naik jumlah pembiayaan modal kerja maka semakin naik pendapatan usaha anggota.

Berdasarkan hasil output tersebut, $t_{\text {hitung }}$ untuk pembiayaan modal kerja sebesar 2,688 dan $t_{\text {tabel }}$ dapat dicari dengan taraf signifikansi $0,05 / 2=0,025$ dengan df (n-2) atau 30-2=28. Didapat $t_{\text {tabel }}$ adalah 2,048. Dapat diketahui 
bahwa thitung $(2,688)>t_{\text {tabel }}(2,048)$ sehingga hipotesis $\mathrm{H}_{0}$ ditolak. Maka dapat disimpulkan terdapat pengaruh yang positif dan signifikan antara jumlah pembiayaan modal kerja dengan pendapatan usaha anggota pada koperasi BMT Ta'awun Finance.

Temuan ini sejalan dengan penelitian yang dilakukan oleh Widya Gina dan Jaenal Effendi pada tahun 2016 tentang "Program Pembiayaan Lembaga Keuangan Mikro Syariah (LKMS) Dalam Peningkatan Kesejahteraan Pelaku Usaha Mikro (Studi Kasus BMT Baitul Karim Bekasi)". Hasil penelitian berupa nilai koefisien sebesar 0.317 pada taraf 5\% menunjukkan besarnya pembiayaan berpengaruh positif signifikan terhadap pendapatan yang diperoleh keluarga. Nilai koefisien sebesar 0.317 memiliki arti bahwa kenaikan pembiayaan sebesar $1 \%$ akan mengakibatkan kenaikan pendapatan rata-rata sebesar $0.317 \%$, ceteris paribus.

Penelitian lainnya yang memperkuat penelitian ini adalah penelitian yang dilakukan oleh Royan Ramdhani Djayusman dan Achmad Nasution pada tahun 2015 tentang "Pengaruh Pembiayaan Mudharabah terhadap Pendapatan Anggota/Nasabah (Studi Kasus di Baitu-t Tamwil AtTamziz cabang Magelang tahun 20122013)". Hasil nilai thitung $(4,090)>$ dari $t_{\text {tabel }}(1,660)$ dengan signifikansi $0,000<$ $\pm(0,05)$ yang berarti (mudharabah) memilih pengaruh yang siginifikan terhadap pendapatan nasabah.

Hasil penelitian ini juga didukung oleh pendapat Bapak Purwono ketika peneliti melakukan wawancara mendalam. Menurutnya, pembiayaan modal kerja yang diberikan BMT Ta'awun Finance menambah modal untuk memperbanyak jumlah barang dagang. Awalnya dia hanya bisa membeli lima karung beras, tetapi permintaan terhadap beras tinggi sehingga lima karung tersebut tidak mampu memenuhi kebutuhan pelanggan lainnya yang ingin membeli. Setelah mendapat pembiayaan modal kerja, bisa menambah jumlah beras menjadi sepuluh karung, begitu pula dengan barang lainnya. Ketersediaan barang dagang tersebut membuat jumlah pembeli bertambah dan persediaan barang dagang berkurang sehingga meningkatkan pendapatan usaha.

\section{Perbedaan Pendapatan Usaha Anggota Sebelum dan Sesudah Menerima Pembiayaan Modal Kerja}

Tabel di bawah ini menerangkan perbedaan pendapatan usaha anggota antara sebelum dan sesudah menerima pembiayaan modal kerja di Koperasi PEMK Cengkareng Timur sebagai berikut:

Tabel. 3

Uji Paired Sample t Test pada Koperasi PEMK Cengkareng Timur Paired Samples Test 


\begin{tabular}{|c|c|c|c|c|c|c|c|c|c|}
\hline & \multicolumn{5}{|c|}{ Paired Differences } & \multirow[b]{3}{*}{$\mathrm{t}$} & \multirow[b]{3}{*}{$\mathrm{df}$} & \multirow{3}{*}{$\begin{array}{l}\text { Sig. (2- } \\
\text { tailed) }\end{array}$} \\
\hline & & \multirow[b]{2}{*}{ Mean } & \multirow{2}{*}{\begin{tabular}{|c|}
$\begin{array}{c}\text { Std. } \\
\text { Deviation }\end{array}$ \\
\end{tabular}} & \multirow{2}{*}{$\begin{array}{c}\text { Std. } \\
\text { Error } \\
\text { Mean }\end{array}$} & \multicolumn{2}{|c|}{$\begin{array}{l}\text { 95\% Confidence } \\
\text { Interval of the } \\
\text { Difference } \\
\end{array}$} & & & \\
\hline & & & & & Lower & Upper & & & \\
\hline $\begin{array}{l}\text { Pair } \\
1\end{array}$ & $\begin{array}{l}\text { Pendapatan } \\
\text { Usaha Anggota } \\
\text { (Konven- } \\
\text { Sebelum) - } \\
\text { Pendapatan } \\
\text { Usaha Anggota } \\
\text { (Konven- } \\
\text { Sesudah) }\end{array}$ &,- 01433 & 01333 & ,00243 &,- 01930 &,- 00935 & $-5,889$ & 29 & ,000 \\
\hline
\end{tabular}

Sumber: Data primer diolah oleh SPSS tahun 2017

Berdasarkan hasil output tersebut, dengan $t_{\text {hitung }}$ sebesar $-5,889$ dengan nilai probabilitas (sig.) $0,000<$ 0,05. Maka dapat disimpulkan Ho ditolak dan Ha diterima yang berarti terdapat perbedaan pendapatan usaha anggota antara sebelum dan sesudah menerima pembiayaan modal kerja pada koperasi PEMK Cengkareng Timur.

Penelitian ini diperkuat oleh penelitian sebelumnya yang telah diteliti oleh Aris Tri Haryanto dan Septiana Novita Dewi pada tahun 2017 tentang "Perbandingan Sebelum dan Sesudah Program Penerapan PNPM Mandiri Dalam Pendapatan Kartu Keluarga Miskin". Berdasarkan hasil Z Zitung (16.195) $>Z_{\text {tabel }}(2,003)$ atau nilai signifikannya $(0,000)<(0,05)$ dengan tingkat kepercayaan 95\% memiliki arti bahwa terdapat perbedaan rata-rata yang signifikan penghasilan perbulan usaha anggota kelompok UPPKS sebelum dengan sesudah adanya PNPM.

$$
\text { Penelitian lainnya yang }
$$
mendukung adalah penelitian yang dilakukan oleh Hanifah Isnaini pada tahun 2013 tentang "Analisa Pengaruh Pemberian Kredit Terhadap Peningkatan Pendapatan Usaha Mikro Di Surakarta
(Pada Koperasi Simpan Pinjam Lumbung Artha)". Hasil penelitian tersebut menunjukkan hasil uji beda dengan Paired Sample t test diperoleh nilai thitung sebesar $-12,709$ dengan $\mathrm{p}=$ 0,000 . Oleh karena hasil perhitungan diperoleh nilai $\mathrm{p}<0,05$ artinya terdapat perbedaan pendapatan pengusaha mikro di Surakarta antara sebelum dan sesudah pemberian kredit.

Hasil penelitian ini juga didukung oleh hasil wawancara mendalam yang dilakukan kepada Bapak Saman. Sebelum mendapatkan pembiayaan modal kerja dari koperasi PEMK Cengkareng Timur, pendapatan yang diperoleh dari hasil berdagang gorengan adalah kurang lebih Rp 60.000 - Rp 70.000 per hari dan setelah mendapatkan pembiayaan modal kerja terjadi peningkatan pendapatan menjadi Rp 80.000 - Rp 85.000 per hari. Hal ini dikarenakan pembiayaan modal kerja yang diterima digunakan untuk membeli bahan - bahan gorengan, seperti terigu, minyak goreng, sayuran, pisang, ubi, dan lain - lain sehingga jumlah barang dagang menjadi bertambah dan pendapatan pun meningkat. 
Berikut hasil uji perbedaan pendapatan usaha anggota antara sebelum dan sesudah menerima pembiayaan modal kerja di BMT Ta'awun Finance:

Tabel. 4

Uji Paired Sample t Test pada BMT Ta'awun Finance Paired Samples Test

\begin{tabular}{|c|c|c|c|c|c|c|c|c|c|}
\hline & & \multicolumn{5}{|c|}{ Paired Differences } & \multirow[b]{3}{*}{$\mathrm{T}$} & \multirow[b]{3}{*}{$\mathrm{df}$} & \multirow{3}{*}{$\begin{array}{l}\text { Sig. (2- } \\
\text { tailed) }\end{array}$} \\
\hline & & \multirow[b]{2}{*}{ Mean } & \multirow{2}{*}{$\begin{array}{c}\text { Std. } \\
\text { Deviation } \\
\end{array}$} & \multirow{2}{*}{$\begin{array}{c}\text { Std. Error } \\
\text { Mean }\end{array}$} & \multicolumn{2}{|c|}{$\begin{array}{l}95 \% \text { Confidence } \\
\text { Interval of the } \\
\text { Difference }\end{array}$} & & & \\
\hline & & & & & Lower & Upper & & & \\
\hline $\begin{array}{l}\text { Pair } \\
1\end{array}$ & $\begin{array}{l}\text { Pendapatan } \\
\text { Usaha Anggota } \\
\text { (Syariah- } \\
\text { Sebelum) - } \\
\text { Pendapatan } \\
\text { Usaha Anggota } \\
\text { (Syariah- } \\
\text { Sesudah) }\end{array}$ &, 12714 & ,03087 & ,00564 &,- 13867 &,- 11561 & 22,558 & 29 &, 000 \\
\hline
\end{tabular}

Sumber: Data primer diolah oleh SPSS Tahun 2017

Berdasarkan hasil output tersebut, dengan thitung sebesar -22,558 dengan nilai probabilitas (sig.) $0,000<$ 0,05. Maka dapat disimpulkan Ho ditolak dan $\mathrm{Ha}$ diterima yang berarti terdapat perbedaan pendapatan usaha anggota antara sebelum dan sesudah menerima pembiayaan modal kerja pada BMT Ta'awun Finance.

Temuan ini diperkuat oleh Penelitian yang dilakukan oleh Pipit Mustofa dan Achma Hendra Setiawan pada tahun 2013 dengan judul "Peran Kredit dari Koperasi Serba Usaha (KSU) Artha Sukses Terhadap Perkembangan Usaha Mikro yang menjadi anggotanya di Kota Semarang". Berdasarkan uji statistik pangkat tanda wilcoxon didapatkan nilai -p sebesar $0,000(0,000$ $<0,05)$ atau nilai $Z_{\text {hitung }}=(-7.274)<Z_{\text {tabel }}$ $=(-1,96)$. Hasil itu menunjukkan terdapat perbedaan pada variabel kredit usaha mikro antara sebelum dan sesudah adanya kredit dari KSU Artha Sukses di Kota Semarang.

Penelitian ini juga diperkuat oleh penelitian yang dilakukan Priyo Harsono pada tahun 2012 mengenai "Analisis Bantuan Kredit Terhadap Perkembangan Kelompok Anggota Usaha Bersama". Berdasarkan uji statistik pangkat tanda wilcoxon didapatkan nilai -p sebesar $0,000(0,000<0,05)$ atau nilai $Z_{\text {hitung }}=(-$ $5,563)>\mathrm{Z}_{\text {tabel }}=1,96$. Hal ini berarti terdapat perbedaan pada variabel keuntungan KUB antara sebelum dan sesudah adanya kredit dari Dinas Kelautan dan Perikanan Kabupaten Pati.

Hasil penelitian ini didukung oleh pernyataan Ibu Rini Tarsini, seorang penjual gorengan dan lontong. Sebelum mendapatkan pembiayaan modal kerja dari BMT Ta'awun Finance, beliau hanya memiliki peralatan seadanya untuk mengolah barang dagangan tersebut. Setelah mendapatkan pembiayaan modal kerja, beliau 
membeli peralatan yang ukurannya lebih besar sehingga terjadi efisiensi waktu, tenaga, dan menaikkan produktivitas untuk menghasilkan barang dagang dalam jumlah yang banyak.

\section{Perbedaan Pendapatan Usaha Anggota antara PEMK Cengkareng}

\section{Timur dengan BMT Ta'awun Finance Setelah Menerima Pembiayaan Modal Kerja}

Untuk melihat perbedaan pendapatan usaha anggota antara koperasi PEMK Cengkareng Timur dan BMT Ta'awun Finance setelah menerima pembiayaan modal kerja dapat dilihat melalui uji independent $t$ sample test sebagai berikut:

Tabel. 5

Uji Independent Sample T Test

Independent Samples Test

\begin{tabular}{|c|c|c|c|c|c|c|c|c|c|c|}
\hline & \multicolumn{2}{|c|}{$\begin{array}{c}\text { Levene's Test } \\
\text { for Equality of } \\
\text { Variances }\end{array}$} & \multicolumn{7}{|c|}{ t-test for Equality of Means } \\
\hline & & \multirow[b]{2}{*}{$\mathrm{F}$} & \multirow[b]{2}{*}{ Sig. } & \multirow[b]{2}{*}{$\mathrm{T}$} & \multirow[b]{2}{*}{ df } & \multirow{2}{*}{$\begin{array}{l}\text { Sig. (2- } \\
\text { tailed) }\end{array}$} & \multirow{2}{*}{$\begin{array}{c}\text { Mean } \\
\text { Difference }\end{array}$} & \multirow{2}{*}{$\begin{array}{l}\text { Std. Error } \\
\text { Difference }\end{array}$} & \multicolumn{2}{|c|}{$\begin{array}{l}\text { 95\% Confidence } \\
\text { Interval of the } \\
\text { Difference }\end{array}$} \\
\hline & & & & & & & & & Lower & Upper \\
\hline \multirow{2}{*}{$\begin{array}{l}\text { Pendapatan } \\
\text { Usaha } \\
\text { Anggota }\end{array}$} & $\begin{array}{l}\text { Equal variances } \\
\text { assumed }\end{array}$ & \multirow[t]{2}{*}{,038 } & \multirow[t]{2}{*}{, 845} & $-4,462$ & 58 &, 000 &,- 08600 & ,01927 &,- 12458 &,- 04741 \\
\hline & $\begin{array}{l}\text { Equal variances } \\
\text { not assumed }\end{array}$ & & & $-4,462$ & 57,894 &, 000 &,- 08600 & ,01927 &,- 12458 &,- 04741 \\
\hline
\end{tabular}

Sumber: Data primer diolah oleh SPSS tahun 2017

Berdasarkan analisis uji t terlihat nilai $t_{\text {hitung }}$ sebesar $0,00<0,05$. Hasil itu dapat disimpulkan Ho ditolak dan $\mathrm{Ha}$ diterima yang berarti ada perbedaan pendapatan usaha anggota yang menerima pembiayaan modal kerja dari PEMK Cengkareng Timur dengan BMT Ta'awun Finance.

Perbedaan ini bisa dilihat dari jumlah pembiayaan yang diberikan oleh masing - masing koperasi. Koperasi PEMK Cengkareng Timur memberikan pembiayaan maksimal sebesar $\mathrm{Rp}$ 5.000.000 sedangkan BMT Ta'awun Finance memberikan pembiayaan modal kerja sesuai dengan kebutuhan anggota sehingga jumlahnya bisa mencapai angka Rp 30.000.000 bahkan lebih dalam sekali pinjam.

Secara statistik, ketika terjadi penambahan modal kerja, maka akan menambah pendapatan anggota. Semakin besar pembiayaan modal kerja yang diberikan, maka semakin besar pula pendapatan yang diperoleh. Hal ini terjadi jika pembiayaan modal kerja yang diterima dimanfaatkan dan digunakan untuk keperluan modal kerja itu sendiri sehingga penyalurannya menjadi tepat sasaran.

Praktik di lapangan, koperasi PEMK Cengkareng Timur memberikan jumlah pembiayaan modal kerja yang lebih sedikit dibandingkan dengan BMT Ta'awun Finance, namun pendapatan yang diterima anggota tidak terlalu beda jumlahnya. Hal ini dikarenakan banyak faktor yang turut serta mempengaruhi pendapatan masing - masing anggota.

Sebagian anggota pada koperasi PEMK Cengkareng Timur diperkuat oleh modal sendiri, modal pinjaman 
lembaga keuangan lain, dan lokasi usaha yang menguntungkan sehingga tidak bergantung pada pembiayaan yang diberikan koperasi tersebut. Ada pula yang memanfaatkan jumlah pembiayaan yang kecil dengan kesesuaian kebutuhan sehingga walaupun jumlahnya kecil tetap mampu menaikkan pendapatan.

Berbeda dengan anggota BMT Ta'awun Finance yang sebagaian besar bergantung pada pembiayaan yang diberikan BMT karena lemahnya modal sendiri dan tidak bergantung pada lembaga lain. Semakin besar pembiayaan yang diberikan, maka mampu menaikkan pendapatan anggotanya.

Teori semakin besar jumlah pembiayaan modal kerja yang diberikan, maka semakin besar pula pendapatan yang diperoleh ini tidak berlaku jika anggota masing - masing koperasi menyalahgunakan pembiayaan yang diperolehnya. Sebesar apa pun jumlah pembiayaan modal kerja yang diberikan, tidak akan mampu meningkatkan pendapatan jika penggunaannya tidak dialokasikan untuk kebutuhan modal kerja.

Lain halnya juga dengan jangka waktu yang diberikan masing - masing koperasi. Koperasi PEMK Cengkareng Timur memberikan jangka waktu yang lebih panjang sebanyak sepuluh bulan kepada setiap anggota pembiayaan, tanpa memperhatikan besar kecilnya jumlah pembiayaan modal kerja yang dipinjam anggota. Hal ini memberikan dampak yang positif karena jumlah angsuran tidak memberartkan anggota, tetapi perputaran uang koperasi menjadi lambat.

Berbeda dengan koperasi PEMK Cengkareng Timur, BMT Ta'awun Finance memberikan jangka waktu yang lebih singkat. Mayoritas anggota pembiayaan diberikan jangka waktu antara $3-6$ bulan. Jangka waktu ini diberikan dengan mempertimbangkan karakter dan kemampuan anggota untuk melunasi pembiayaan yang diberikan. Semakin cepat dilunasi, maka semakin cepat pula anggota mendapatkan kesempatan untuk mengajukan pembiayaan kembali jika karakteristik anggota dianggap layak.

\section{KESIMPULAN}

Berdasarkan hasil penelitian maka dapat disimpulkan tiga hal. Pertama, terdapat pengaruh positif dan signifikan antara pembiayaan modal kerja terhadap pendapatan usaha anggota, baik pada koperasi PEMK Cengkareng Timur maupun BMT Ta'awun Finance. Artinya, semakin besar jumlah pembiayaan modal kerja, maka akan semakin besar tingkat pendapatan usaha anggota. Kedua, Terdapat perbedaan pendapatan usaha anggota antara sebelum dan sesudah menerima pembiayaan modal kerja, baik pada koperasi PEMK Cengkareng Timur maupun BMT Ta'awun Finance. Artinya, ada perubahan pendapatan yang diterima masing - masing anggota koperasi setelah memperoleh pembiayaan modal kerja dari koperasi yang bersangkutan. Ketiga, Terdapat perbedaan pendapatan usaha anggota antara koperasi PEMK Cengkareng Timur dengan BMT Ta'awun Finance setelah menerima pembiayaan modal kerja.

Salah satu upaya meningkatkan pendapatan usaha anggota, baik koperasi PEMK Cengkareng Timur dan BMT Ta'awun Finance yaitu dengan cara memberikan jumlah pembiayaan modal kerja yang sesuai dan tepat sasaran. 
Besar kecilnya jumlah pembiayaan modal kerja yang koperasi maupun BMT berikan menentukan tingkat pendapatan usaha anggota. Semakin besar jumlah pembiayaan modal kerja yang diberikan maka akan semakin besar pula pendapatan usaha yang akan anggota peroleh. Hal ini dapat terealisasi jika anggota koperasi benar - benar menggunakan dan memanfaatkan pembiayaan modal kerja tersebut sesuai dengan kebutuhan modal kerja.

Koperasi PEMK Cengkareng Timur dalam menentukan jangka waktu pengembalian pembiayaan perlu memperhatikan jumlah pembiayaan yang diberikan. Tidak menyamaratakan pengembalian pembiayaan selama 10 bulan antara pembiayaan yang berjumlah kecil dengan yang berjumlah besar. Jika jumlah pembiayaan yang disalurkan lebih kecil, maka jangka waktu yang diberikan lebih pendek. Jika jumlah pembiayaan lebih besar, maka jangka waktu yang diberikan lebih panjang. Penentuan jangka waktu ini bertujuan agar menyesuiakan dengan kemampuan anggota dalam membayar cicilan tiap bulannya dan agar tidak memperlambat perputaran uang koperasi untuk menyalurkan pembiayaan berikutnya.

BMT Ta'awun Finance bisa meningkatkan jumlah pembiayaan modal kerja yang disalurkan. Jika hal ini BMT lakukan, maka keberadaan BMT semakin memiliki manfaat bagi anggota, khususnya anggota pembiayaan modal kerja. Semakin tinggi tingkat pendapatan usaha anggota, semakin besar nilai bagi hasil bagi BMT, maka akan berdampak terhadap keberlangsungan BMT untuk melakukan perputaran uang dan memperoleh profitabilitas yang tinggi.

\section{DAFTAR PUSTAKA}

\section{Buku}

Akmaluddin Suangkupon, et.al. 2014. Direktori Produk Kredit dan Tabungan Perbankan: Se- Kalimantan Tengah Tahun 2014. Kalteng: Unit Akses Keuangan dan UMKM KpwBI Prov. Kalteng

Gunadi. 2009. Akuntansi Pajak: Sesuai Undang - Undang Baru. Edisi Revisi. Jakarta: Grasindo

Hendrojogi. 2012. Koperasi: Asas - asas, Teori, dan Praktik. Cetakan ke - 9. Jakarta: Rajawali Pers

Ikit. 2015. Akuntansi Penghimpunan Dana Bank Syariah. Yogyakarta: Deepublish

Ismail. 2011. Manajemen Perbankan: Dari Teori Menuju Aplikasi. Jakarta: Kencana

Kasmir. 2011. Dasar - Dasar Perbankan. Cetakan ke-9. Jakarta: Rajawali Pers

Kettel, Brian. 2011. Introduction to Islamic Banking and Finance. United Kingdom: Wiley Finance

Machfoedz, Mahmud. 2007. Pengantar Bisnis Modern. Yogyakarta: Penerbit ANDI

Margaretha, Farah. 2011. Manajemen Keuangan untuk Manajer Non Keuangan. Jakarta: Erlangga

Nikensari, Sri Indah. 2012. Perbankan Syariah: Prinsip, Sejarah, dan Aplikasinya. Semarang: PT. Pustaka Rizki Putra

Sahroni, Oni dan Adiwarman A Karim. 2015. Maqashid Bisnis \& Keuangan Islam: Sintesis Fikih dan Ekonomi. Jakarta: Rajawali Pers

Saija, R dan Iqbal Taufiq. 2016. Dinamika Hukum Islam Indonesia. Yogyakarta: Deepublish

Sholihin, Ahmad Ifham. 2010. Buku Pintar Ekonomi Syariah. Jakarta: PT Gramedia Pustaka Utama

Tiby, Amr Mohamed El. 2011. Islamic Banking: How to Manage Risk and 
Improve Profitability. New Jersey: Wiley Finance

\section{Jurnal}

Amir Halid, Ria Indriani, dan Delvi Suleman. "Pengaruh Jumlah Kredit dan Suku Bunga Terhadap Pendapatan Usaha Mikro di BRI Unit Kabila”. Jurnal Perspektif Pembiayaan dan Pembangunan Daerah, Vol. 1 No. 3, Januari-Maret 2014, ISSN: 2338 - 4603

Cut Yusriati, Muhammad Arfan dan M. Rizal Yahya, "Pengaruh Pinjaman Modal Kerja dan Profesionalisme Sumber Daya Manusia Terhadap Laba Usaha Kecil Menengah Kota Banda Aceh". Jurnal Akuntansi. Vol. 1 No.1, November 2012, ISSN: $2302-0164$

Djayusman, Royan Ramdhani dan Achmad Nasution. "Pengaruh Pembiayaan Mudharabah terhadap Pendapatan Anggota/Nasabah (Studi Kasus di Baitut Tamwil At-Tamziz cabang Magelang tahun 2012-2013). Islamic Economic Journal. Vol. 1 No.1, Juni 2015, ISSN: 2460 - 1896

Gina, Widya dan Jaenal Effendi. "Program Pembiayaan Lembaga Keuangan Mikro Syariah (LKMS) Dalam Peningkatan Kesejahteraan Pelaku Usaha Mikro (Studi Kasus BMT Baitul Karim Bekasi)". Jurnal Al-Muzara'ah, Vol. 3 No.1, 2016, ISSN p: 2337-6333; e: 23554363

Harsono, Priyo. "Analisis Bantuan Kredit Terhadap Perkembangan Kelompok Anggota Usaha Bersama. Journal of Economics and Policy. Vol. 5 No.2, 2012, ISSN: 1979-715X

Haryanto, Aris Tri dan Septiana Novita Dewi. "Perbandingan Sebelum dan Sesudah Program Penerapan PNPM Mandiri Dalam Pendapatan Kartu Keluarga Miskin”. ProBank: Jurnal
Ekonomi dan Perbankan, Vol. 2 No. 1, 2017, ISSN 2579-5597)

Isnaini, Hanifah. "Analisa Pengaruh Pemberian Kredit Terhadap Peningkatan Pendapatan Usaha Mikro Di Surakarta (Pada Koperasi Simpan Pinjam Lumbung Artha)". Artikel Publikasi Ilmiah, 2013

Mustofa, Pipit dan Achma Hendra Setiawan. "Peran Kredit dari Koperasi Serba Usaha (KSU) Artha Sukses Terhadap Perkembangan Usaha Mikro yang menjadi anggotanya di Kota Semarang”. Diponegoro Journal of Economics, Vol. 2 No. 3, 2013 